Marquette University

e-Publications@Marquette

College of Nursing Faculty Research and

Publications

Nursing, College of

$1-1-2003$

\title{
Te Contaria Mi Vida: I Would Tell You My Life, if Only You Would Ask
}

Ruth Belknap

Marquette University, ruth.belknap@marquette.edu

Pilar Sayeed

Marquette University

Accepted version. Health Care for Women International, Volume 24, No. 8 (2003). DOI. (C) 2003

Taylor \& Francis. Used with permission. 


\title{
Te Contaria Mi Vida: I Would Tell You My Life, if Only You Would Ask
}

Ruth Ann Belknap, PhD, APRN, BC, and Pilar Sayeed, MSN, RN; College of Nursing, Marquette University, Milwaukee, Wisconsin, USA

\begin{abstract}
Universal screening for domestic violence is recommended in many health care settings. This qualitative study was undertaken to explore the thoughts and feelings of Mexican American women regarding being asked questions about domestic violence by a health care provider. We wanted to further explore what characteristics about a nurse, or other health care provider, would give a woman confianza, the trust necessary to discuss this issue. Seven women, who self identified as abused or formerly abused, were recruited from a pool of Spanish-speaking women receiving services from a rural domestic violence agency in the midwestern United States. The researchers found that, given certain characteristics and actions of the health care provider, women welcome the opportunity to discuss this issue. The implications for practice are these: be sincerely present for the client, ask about her life, listen to her response, and when necessary assist her to connect with appropriate domestic violence community services.
\end{abstract}

There is an urgent need for increasing knowledge that will lead to culturally congruent care in society. I became interested in exploring how health care professionals can best screen for domestic violence in the course of my work as a women's counselor in a domestic violence shelter. As I talked with Mexican American women, it became clear that none had ever had a doctor or nurse ask about abuse or violence. Most of the women were isolated from support systems that would help them end the abuse they were experiencing or cope with the effects of abuse they had experienced. I began to wonder how women would respond if they were asked routine screening questions and how these questions might be asked in a culturally congruent way. The necessity for interviewing techniques that are culturally appropriate is especially acute in today's health care environment where nurses and other providers are under extreme time constraints. A question that is asked in a way that it inhibits the client's response, or a question not asked, may miss the only opportunity the provider has to uncover serious threats to the woman's health and life. These threats include physical violence and/or emotional abuse from her partner. This study utilized ethnonursing research methods to explore thoughts and feelings women have about assessment screening for domestic violence and to develop suggestions for culturally congruent nurse client interactions. 


\section{Background and Significance}

The dangers of life in a violent home are intensified for battered immigrant women. These women face not only danger in their homes but also struggle with discrimination based on their gender, race, and immigration status. A study by the Immigrant Women's Task Force of Northern California Coalition for Immigrant Rights revealed that 34\% of Latinas experience domestic violence either in their country of origin or in the United States (Family Violence Prevention Fund, www.endabuse.org/programs/immigrants).

Researchers are beginning to examine cultural similarities and differences in women's responses to and experiences of abuse. Several studies have focused on Latina populations. Of interest here are studies that have examined help-seeking behavior and those that have examined assessment and screening. West, Kantor, and Jasinski (1998) found that Latinas utilized fewer formal and informal resources than Anglo women, with Mexican women being the least likely to seek assistance. Low acculturation was identified as a barrier to help seeking. Hook (2000) found Latinas more likely to seek help from a clinic than African American women. However, Latinas reported more barriers to talking about abuse, citing lack of time during appointments as a particular barrier.

In a recent study Wilson and colleagues (2001) utilized a convenience sample of 149 abused women (of which $29 \%$ were Latina/Hispanic) and found that although $86 \%$ of the women had sought health care in the previous year, only $24 \%$ had been assessed for interpersonal violence. Feldhaus and colleagues (1997) developed a three-question screening tool, the partner violence screen (PVS). They compared sensitivity, specificity, and predictive value of the PVS with two standardized measures, the 30-item Index of Spouse Abuse and the 19-item Conflict Tactics Scale. In this study of 322 women (30\% Hispanic), in two urban emergency departments, the PVS was found to be less than optimal in sensitivity. The PVS detected $64.5 \%-71.4 \%$ of women who had a history of interpersonal violence in the previous year. McFarlane, Christoffel, Bateman, Miller, and Bullock (1991) found significant differences in positive responses for abuse between self-report questionnaires and nurse interviews. The positive response rate for self-report was $8.2 \%$ compared with $29.3 \%$ for nurse-conducted interviews.

A review of the literature revealed one study specific to cultural factors affecting communication during domestic violence screening. Rodriquez, Bauer, Flores-Ortiz, and Szkupinski-Quiroga (1998) conducted a focus group study that identified provider behaviors that facilitate patient-provider communication for two groups, abused Latinas and Asian immigrant 
women. Their findings support the necessity of improving communication in order to facilitate the provider's ability to offer meaningful support to these clients.

\section{Study Overview}

\section{Theoretical Framework}

I utilized Leininger's Culture Care theory as the organizing framework for this study. According to Leininger, the purpose of culture care theory is to, "discover human care diversities and universalities ... then to discover ways to provide culturally congruent care to people of different or similar cultures in order to maintain or regain their well being, health, or face death in a culturally appropriate way" (Leininger, 2001, p. 39). This theory provides a framework for discovery through use of ethnonursing methodology. Ethnonursing methodology as developed and described by Leininger (1985) is suited specifically for examining nursing phenomena across cultures, to obtain data, and to focus on narrower aspects of human care concepts.

In this study I looked at one such narrow aspect. The purpose of this inquiry was to explore women's thoughts and feelings about being asked abuse assessment questions by a nurse or health care provider, to describe women's perceptions of the usefulness of abuse screening, and to identify specific behaviors women desired from a nurse or health care provider during the screening process.

The research questions include the following: What do women think/feel when asked routine domestic violence screening questions? What characteristics of the interview process assist a woman to speak about abuse/violence in her life? What characteristics of the nurse (or health care provider) will enhance the possibility that the client will feel comfortable discussing abuse/violence? What characteristics inhibit disclosure of abuse/violence?

\section{Methods}

\section{Stranger to Friend}

One of the major enablers of the ethnonursing method is for the researcher to move from stranger to trusted friend role (for a full discussion of enablers, see Leininger 2001, chapter 2). I am a middle-aged Caucasian woman. I began the process of moving from stranger to trusted friend prior to the implementation of this research project. Approximately 3 years before this study began, I worked several hours a week as a counselor at a domestic violence agency. At first, I saw only women who were bilingual or had monolingual English fluency. As time went on I began seeing more and more women who recently had immigrated to this area from Latin America, primarily Mexico. The women had limited English language skills. The need for a 
support group meeting in Spanish became apparent, so I became cofacilitator of the group. As Leininger (2001) suggested, due to the close link between language and culture, studies of culture care phenomena may require the nurse to learn the language of the culture. At the time this work began my Spanish language skills were minimal. Therefore, I started formal education classes in Spanish, attended a Spanish language and cultural immersion experience in Mexico, and spent several hours a week with families who spoke only Spanish. Although my understanding of the language increased, I continued to work with a bilingual/bicultural interpreter. My efforts to interact in Spanish were important in assisting to build a relationship with the women in the support group. My status as stranger began to evolve as the women accepted me as a partner in the group process.

Women were asked by the interpreter (a woman who was familiar to them) to participate in this study; I was not present at the time this inquiry was made. All women who were asked to participate agreed to do so. I knew all of the women prior to the interview. Some I had met only one or two times; others I knew quite well. Women were given a choice of interview location: at the agency, at the home of the interpreter, or other location of their choosing. All women chose to be interviewed in the home or at the agency. Institutional review board approval was obtained from the university and informed consent was obtained from the women prior to data collection. The women were asked to choose a pseudonym to be used during the interview so that their names would not appear in the transcripts; these names were also used throughout the data analysis process and in the writing of this article.

\section{Description of Participants}

A purposive sample of 7 women (3 described themselves as married but separated and 4 as married) was obtained for in-depth interviews. Inclusion criteria were immigration to the United States from Mexico and self-identification as having experienced or currently experiencing an abusive relationship with a male intimate partner. Age range of the women at the time of the interview was 19 to 38; the mean age was 30. All of the women are mothers: The number of children ranged from 1 to 5 , with children ranging in age from 1 year to 23 years; all of the women had toddlers or school age children residing at home. The average number of children was 2. The women all had limited English language skills; their time in the United States ranged from 1 year to 15 years. Six had resided in this geographic area for less than 3 years; 2 had been in this area for only 1 year. Four women described their home in Mexico as a rural area or small town; 3 came to the United States from urban centers in Mexico. Two women worked full time; the others were not employed at the time of the interview. 


\section{Data Collection}

Participant observation and focused interviews were used to collect data. The interviews consisted of a series of open-ended questions, conducted in Spanish, and tape-recorded. Throughout the course of the interview women were encouraged to continue with thoughts prompted by open-ended questions. Although the interviews were guided, there was substantial opportunity for the women to respond and express themselves beyond the questions asked, and most of the women did so.

\section{Data Analysis}

The interviews were transcribed verbatim in Spanish. Following transcription, I added a bicultural/bilingual graduate research assistant to the project. To increase accuracy of the transcriptions, the research assistant listened to the tapes and made any needed corrections to the transcripts. Data analysis proceeded using these written transcripts and field notes made by the researcher at the time of the interview. Transcripts were read in Spanish and coded according to themes related to the specific research questions. Each transcript was read and coded by the researcher and the research assistant. Translation to English was made at the point that a specific piece of data was coded as informative to a specific research question. The interpreter who had assisted with the interviews then confirmed these translations and codes.

\section{Findings}

\section{Establishing the Dialogue}

To begin each interview at a relational and interpersonal level, each woman was asked to describe herself. Initially hesitation was detected in the women's descriptions. Several began by simply saying, "No sé," "I don't know." Following this initial hesitation, women began to describe themselves slowly. They consistently seemed to have difficulty finding words to describe self. Most of the women began with a few adjectives, ranging from inseguro (insecure, uncertain), cohibido (shy), and deprimida (depressed) to alegre (happy, cheerful), en paz (in peace), and más fuerte (stronger). Often this description was followed by a story about an important event in her life. Most of the women included their children in their descriptions. Themes in these stories included a longing for Mexico and the familiar way of life found there, a strong identification of self as mother, and the direction for life found in caring for one's children.

At this point women were asked who they might talk to if the were having problems such as paying bills or finding a place to live. Women responded that they would talk with family 
(parents, sister) or a friend. Three women specifically mentioned the domestic violence agency, stating that this agency had been helpful to them with such problems.

After these introductory questions conversation was typically relaxed and comfortable. The topic of relationship problems was introduced at this point with the question, "Whom do you/women talk to when you/they have problems with your/their husband/boyfriend?" Women indicated they would talk with their parents, sister, or a good friend. They specifically described sisters and friends who understood their situation, either because they knew them quite well or because they themselves were in similar situations:

Abril: Pienso que normalmente lo hacen con su amiga más cercana o alguna familiar prima, hermana. Pero por lo regular creo que es alguien que pueda entenderla y que se encuentre en la misma situación.

I think usually they would talk with a close friend or relative, cousin, or sisternormally, I believe, someone who is able to understand her and who is in the same situation.

Interviewer: ¿Con quien hablas tu? (Whom do you talk to?)

Abril: La primera persona que sabe toda mi situación es una amiga mía, que también es casada, también tiene dos hijos. Es de mi misma edad. Trabajaba conmigo. La conozco desde que llegue aquí y ella conoce mi vida desde que llegue aquí. Después de ella la otra persona que conoce o que he platicado, pues, es una persona que se dedica a ayudar gente con estos problemas.

The first person who knows my situation is my friend. She also is married and has two children. She is my age. I work with her. I have known her since I arrived here, and she knows my life from when I came here. After her the person that I know or that I have talked to is, well, a person that helps people with these problems. (She then says it is the Hispanic advocate from the domestic violence agency.)

A second strong theme heard in these responses was that if your family is not nearby, or if you do not have a good friend, then you talk to no one.

Ángeles: Um, depende, si tienes una amiga, pero si no tiene amigas no hablas con nadie no mas te quedas ahí.

It depends, if you have a friend, but if you don't have friends, then you don't talk with anyone-you are left there.

\section{Women's Thoughts and Feelings About Domestic Violence Screening Questions}


A series of questions and prompts was used to find out whether women had been asked about abuse, violence, or similar problems in their lives. Each said she had never been asked such questions. Frequently the woman seemed surprised and responded emphatically, "No, nunca." One woman said perhaps no one asked because her husband was translating for her. Mari responded similarly:

Mari: No. Nunca, nunca, nunca. Nunca me habían preguntado. Cuando yo en México y aquí en (mentions state name). Me sentía muy mal. . . . Yo iba con mis hijos a las vacunas tenía una amiga muy buena, que era enfermera y ella siempre me decía, ¿Mari hoy te veo muy triste tienes algún problema?" Y nunca se lo podía contar. Yo siempre le decía, "O no, estoy muy bien." Pero era mentira. Pero nunca pude contarle mi problema porque él siempre iba conmigo.

No, never, never, never. Never have they asked this question in Mexico or here. I felt very bad. . . . I went with my children for their vaccinations and I had a good friend. She was a nurse and she always said to me, "Mari today you look very sad. Is there a problem?" And never could I tell her. I always said, "Oh, no, I am fine." But it was a lie. But I could never tell her my problem because he (her abuser) always went with me.

Women were asked what they thought about being asked by a doctor or nurse about abuse. Most of the women responded that they thought it would be good to be asked. Although none of the women had experienced being asked such a question, five women indicated that they would answer openly. One of the younger women, who earlier in the interview repeatedly indicated that she had no one to talk to about her problems, answered:

Lorena: Le contaría mi vida, que no me siento a gusto aquí. Hm, hum un tiempo me sentía muy sola, y quería hablar con alguien pero no tenía nadie. (Crying)

I don't know. I would tell him my life, that I am not happy here. I feel lonely. I want to talk with someone, but I don't have anyone.

Others said it would help women to be asked this question:

Abril: Pienso que, seria una buena idea de poder ayudar a la mujer Hispana. .. . $Y$ tal vez si un doctor cualquiera que sea le pregunta acerca de eso podría abrir un poco esa platica y a la mejor darse cuenta de que problabamente si es victima. Porque yo pienso que la mayoría de las Hispanas estamos aquí de alguna manera sufrimos por ese tipo de abusos y aun no se lo contamos a nadie.

I think it would be a good idea to help Hispanic women. . . Maybe if a doctor asks her this question she will be able to open up a little and realize that maybe 
she is a victim. I think that most Hispanic women here suffer these types of abuse even though we don't tell anyone.

Similarly,

Ángeles: A lo mejor esta bien porque hay veces que uno no tiene ni quien se interese en uno. $Y$ a lo mejor seria una forma de saber que a uno le interesa.

Maybe it is good because there are times that one does not have anyone who is interested in one. And that might be a way to find out that someone is interested in her.

Two women indicated that they would be afraid to answer such a question truthfully if there was abuse and that other women also might have reasons to be afraid to answer such a question truthfully. However, these women did not entirely reject the notion that health care providers might ask the question. Later in the interview one of the women responded:

Alei: Yo pienso que una enfermera si lo podría hacer. Si pero ya tendría que haber conocido mas a esas pacientes. . . . Sí, no en la primera vez. En la primera vez lo que ella podría hacer es darle una tarjeta, si . . . entonces ya la persona la va a ver y la va conservar o que sé yo. Pero si la enfermera vuelve a ver esa persona. Le vuelve a platicar y ya va haber un poco más de confianza.

I think that a nurse could do it (give information), but she would have to have known the patients. Yes, not the first time. The first time she could give her a card (from the domestic violence agency), and then if the person returns she can ask again and this time there will be more trust.

\section{Factors That Enhance and Inhibit Disclosure and Discussion of Abuse}

A series of open-ended questions and prompts was used to engage in a dialogue about what the women felt would help them or inhibit them from talking about these problems in their lives. The prompt used began, "What about a doctor or a nurse would give a woman confidence to talk to him/her about her problems, especially difficult personal problems, say, with her husband?" Data obtained from this question was very rich in detail regarding what characteristics and behaviors enhance this communication. Three themes emerged from the data: presence, taking time to listen, and showing an interest in the client's life.

\section{Presence}

Many of the women described a feeling of confidence they gained when health care providers exhibited certain interpersonal characteristics and behaviors. They also described the absence of confidence when these characteristics and behaviors were not present. The term presence has been chosen here to represent the constellation of characteristics and behaviors 
described by the women. Exemplars from the narratives that represent the theme of presence follow:

Ángeles: Sientes la confianza de la primera vez que lo miras.

You feel the confidence the first time you see him.

. . . esta un doctor cuando estaba embarazada de mi niño. Um, a verlo como simplemente como me preguntaba como estaba no sé, seria su voz. Pero yo sentía que era bueno y me ayudó mucho. Me ayudó mucho. Y había un compañero de él pero no él era diferente como su voz su presencia. Como que me ponía nerviosa. . . . Pero ya el doctor que me atendía me ayudó dar luz a mí bebí, yo sentí que todo fue fácil. Se me hizo bien, como si siempre sentí eso me gustaba que él me atendiera él. Y siempre me preguntaba, ¿Cómo estas? ¿Cómo te ha ido esta semana? ¿Que te duele? Y preguntas así y el otro no, no más. Llegaba y decía, ¡Acuéstate allí y me media y ya! (Laughs) ¡Estas bien y ya! Pero no me preguntaba así, ¿Cómo estas? No me hacia sentir de la confianza. Por eso digo, que uno siente cuando puedes confiar en una persona.

. . . the doctor when I was pregnant with my son. He simply asked me how I was. It could be his voice, but I felt that he was good and he helped me a lot. He had a partner but he was different with his voice and his presence. I was nervous. But the doctor who helped deliver my baby, I felt everything was easy. I liked the way he attended to me. He always asked me, "How are you?" "How was this week?" "Do you hurt?" and other questions like this, and the other one didn't. I arrived and he said, "Lay down there" and he would measure me, and that was it. (Laughs) "You are fine!" But he didn't ask, "How are you?" I didn't feel confidence. Because of this I say that one is not able to have confidence in a person.

Laura: A mí me gustaría hablar con una doctora no con doctor porque le tiene uno más confianza a las doctoras para tenerle confianza de decirle los problemas, si yo fuera con una doctora que tuviera buen carácter, tuviera uno la libertad de desahogarse con ella tus problemas.

I would like to talk with a woman doctor because she gives you more confidence to tell her your problems. If I go to a (woman) doctor that had a good personality, I would feel free to pour my problems out to her.

Pues, se mira la gente cuando le caes bien. Una persona que te mira y luego te voltea la cara. Y la otra persona, no ella, te sonrió y te hace platica o sea que tiene mucho que ver eso.

Well, you can tell when somebody likes you. A person who looks at you and then turns her face, and the other person, not her, smiles at you and makes conversation. In other words, that has a lot to do with it.

\section{Taking Time to Listen}


Listening was described consistently throughout the narratives as very important in contributing to the woman's confidence to discuss her situation. Not listening was specifically described as inhibiting what the woman would say:

Sandra: Yo pienso que lo mejor que un doctor debe hacer es tratar de escuchar. Escuchar. Porque hay muchas veces que aunque te preguntan y tu les dices. Pero entonces tu no le puedes contarles bien porque ellos, los doctores nunca tienen tiempo para estar ahí escuchando.

I think it is best that the doctor tries to listen. To listen. Because many times although they ask questions and you answer, you are not able to tell them well because the doctors never have time to listen.

Mari: (When asked if she could describe characteristics of a doctor or nurse that would help her describe her problems.) No, yo digo que no porque, yo pienso que cuando va uno al doctor por muy mal que se sienta. El doctor no va atender uno con para que le platique uno sus problemas. Porque él va decir, "Estoy perdiendo mi tiempo yo tengo más pacientes." Y nunca en mi mente esta que ni una enfermera ni un doctor podrían escuchar problemas solos que fuera una profesional de escuchar problemas de las personas. También este ya después al ultimo yo no contaba nada porque yo tenia miedo.

No, I say, "no," because I think that when you go to a doctor because you feel very bad, the doctor is not going to attend to you by talking about your problems. $\mathrm{He}$ is going to say, "You are wasting my time. I have a lot of patients." Never in my mind is a nurse or doctor able to listen to problems, only if he were a professional in listening to people's problems. And also in the end I didn't tell because I was afraid.

\section{Showing an Interest in the Client's Life}

Women said they felt they could talk with nurses and doctors who showed an interest in their lives. Even women who indicated that talking about abuse and violence is difficult said that if at first the health care provider showed an interest in her as a person, then she might feel confident to discuss this issue. Abril was very specific in her recommendations about what would help women who are hesitant to discuss these issues:

Abril: No ser agresivo y tal vez sí le preguntara que, ¿Esta haciendo tu esposo en este momento? Abordar más hacia preguntas sobre el esposo. O que, ¿Cómo se lleva con su esposo? A mi lo personal no me asustaría que me lo preguntaban. Pero pienso que hay gente y sobre todo Hispana, que no esta acostumbrada de hablar es esto. Se asustaría también ó tal vez tendrían que empezar hablar otras cosas. 
Not be aggressive and maybe ask a question like, "What is your husband doing at the moment?" Approach by asking questions about the husband: "Do you get along with your husband?" Personally I would not be frightened to be asked this. I think certain people, in particular Hispanics, are not accustomed to speaking about this. They would be frightened or you would need to talk about something else.

Se pudiera hacer como para hablar sobre los asuntos de una manera delicada. No sé, a veces nos gusta que nos pregunten. Si nos dedicamos tiempo para nosotras, y además de ser amas de casa ó trabajadoras hacemos algo diferente, en donde no incluyamos a los hijos, podría ser alguna manera como para poder comenzar algo así. Eso es clave porque la manera de contestar de ella decir no yo salgo de mi casa. Yo siento que ya es un abuso.

You could begin by speaking about it delicately. I don't know, sometimes we like being asked if we dedicate time to ourselves, besides being housewives or working, do we do things that don't include the kids. That could be a way you could begin to ask. That is key, because if she says, "I don't leave my house," I feel that is a form of abuse.

Other suggestions included beginning by asking about the woman's children, because, "Women feel confidence in a nurse who is interested in her children, so to begin there is good."

Two women seemed to have difficulty responding to these prompts. Mari did not think that doctors or nurses would be concerned with listening (see quote above). Lorena responded simply, "No sé," then continued to explain that she would talk with her sister-in-law about such problems. It was as if the possibility of a nurse or doctor discussing her problems was simply outside her frame of reference.

\section{Discussion/Conclusions}

This study was conducted in an effort to understand what Mexican American women think and feel about being asked screening and assessment questions regarding domestic violence and to find culturally congruent ways to approach this issue. All of the women in the sample had experienced abuse by a partner, yet none had been asked by a health care provider questions about abuse. This is an important consideration in the interpretation of the findings and limits their transferability. Although responses to the hypothetical situation give important insight, these responses may or may not be similar to responses by women who have experienced screening. The transferability of the current findings is also limited to a fairly narrow age range of women. Middle-aged and older women may have a different perspective on this issue. Also, each of the women had received some form of assistance from the domestic violence agency. Type and amount of assistance varied and included shelter, counseling, court 
advocacy, and participation in a support group. Women who have not had support for coping with abuse may not be as likely to identify the benefits of discussing this problem with a nurse or doctor.

As each woman revealed that she had never been asked about violence or abuse, she was then asked to respond to the hypothetical question, "What would you think about being asked this question?" Responses were very similar: Five of the women clearly stated that they thought it would be a good idea and helpful to women. The 2 women who did not respond in this way gave responses that indicated they would have difficulty imagining that such a circumstance ever might occur. These findings are congruent with findings from other larger studies that were not specific to Mexican American culture and in which participants had experienced screening for domestic violence. Caralis and Musialowski (1997) found that the majority of the women in their study $(N=406)$, conducted in ambulatory clinics in Miami, Florida, USA, felt that doctors should routinely screen for abuse and offer information on community resources as part of treatment. In a study conducted in Queensland, Australia $(N=1500), 98 \%$ of women surveyed following routine screening said they believed it was a "good idea" to screen for domestic violence (Webster, Stratigos, \& Grimes, 2001).

The women who participated in this study gave very detailed information regarding what creates confianza (trust) in a doctor or nurse. Clearly the most important factor is how the health care provider interacts with the client. Sincere acts of presence, such as a smile, a question that demonstrates interest in her as a person, and listening to her are very likely to determine how much she is comfortable revealing. The findings are not surprising in that they are similar to what other studies have found regarding what constitutes culturally congruent care for Mexican Americans (Berry, 1999; Stasiak, 1991/2001; Warda, 2000). They mirror Rodriquez and colleagues' (1998) findings in their focus group study that looked at factors affecting patientphysician communication with abused Latina and Asian immigrant women. Rodriquez and colleagues report that trust, compassion, and understanding improved communication. They also found that women want providers to ask about partner abuse.

Women also indicated that building trust is a process that may take more than one interaction with the health care provider, supporting the practice of asking every woman on every visit about abuse and violence. Two women said specifically that in the past their abuser had been present during routine visits or was acting as interpreter for her. This makes dramatically clear the necessity of asking these questions in private with an interpreter other than the woman's partner. The women in this study had very limited access to health care, most 
frequently accessing health care for their children rather than for themselves, supporting the inclusion of screening questions for the mother during clinic visits for the children.

Nurses cite several restraining factors to routine screening, including discomfort with asking direct questions about abuse, lack of time, feelings of helplessness, and lack of knowledge about abuse (Ellis, 1999; Gagan, 1998; Smith, Danis, \& Helmick, 1998). The women's interview responses support the importance of nurses moving past these restraining factors. All the women I interviewed had experienced the isolation that accompanies an abusive relationship and all supported the benefits of talking with someone about the abuse. Most women specifically cited the services they received from the domestic violence agency as being very helpful to them. Mari's narrative was, in part, a glowing testimony to the woman who had assisted her to connect with a domestic violence services provider. She repeatedly described how these services had helped her to escape from her violent partner and create a new violence-free life for herself and her children. Nurses and other health care providers are in a position to act as cultural brokers and assist women to connect with needed services.

Too often we do not ask the question because we are afraid the answer will be yes, and then what do we do? There is no prescription, no easy answer. Yet as primary care providers there are two very important things that can be done. The first is to offer immediate safety planning and second to connect the client with culturally congruent services within the community. Rodriguez (1999), in her participatory action research with Latina migrant farmworker women, demonstrated how what she has called "the power of the collective" can generate safety nets for women in their communities. Essential processes of the development of this power are liberation, enlightenment, and conscientization. These processes occur as women join together and learn from one another. Helping women connect with one another and with available domestic violence resources is a powerful step toward ending the violence in women's lives.

It is imperative to provide culturally congruent care for abused women. This study supports the importance of presence, listening, and making connections in the care of Mexican American women. I submit that being present, listening, knowing resources, and making connections are more than culture specific interventions. Women and nurses around the globe are longing for these interventions. Varcoe (2001), in a study conducted in two urban hospitals in Canada, found that in the emergency setting abuse often is unrecognized and obscured through "efficient patient processing" and stereotypical thinking. All the women interviewed in her study spoke of the importance of listening. In a study conducted in Australia (McMurray \& Moore, 1994), abused women described the need for being listened to and knowing that the 
nurse was "close." It seems possible that the activities of presence, listening, and making connections have the potential to mediate both restraining and obscuring factors in diverse settings.

\section{Notes}

- The authors are grateful to Frances Martínez for her assistance in translation; Patricia Fox, $\mathrm{PhD}, \mathrm{RN}, \mathrm{FAAN}$, for her assistance in editing this manuscript; and to all the women who so willingly shared their experiences with us for this project.

- Address correspondence to Ruth Ann Belknap, College of Nursing, Marquette University, Clark Hall, P.O. Box 1881, Milwaukee, WI 53201-1881, USA. E-mail:

rbelknap@Marquette.edu

\section{References}

Berry, A. (1999). Mexican American women's expressions of the meaning of culturally congruent prenatal care. Journal of Transcultural Nursing, 10, 203-212.

Caralis, P. V., \& Musialowski, R. (1997). Women's experiences with domestic violence and their attitudes and expectations regarding medical care of abuse victims. Southern Medical Journal, 90(11), 1075-1080.

Ellis, J. (1999). Barriers to effective screening for domestic violence by registered nurses in the emergency department. Critical Care Quarterly, 22(1), 27-41.

Feldhaus, K. M., Kozoil-McLain, J., Amsbury, H., Norton, I., Lowenstein, S., \& Abbott, J. (1997). Accuracy of 3 brief screening questions for detecting partner violence in the emergency department. Journal of the American Medical Association, 277, 1357-1360.

Gagan, M. (1998). Correlates of nurse practitioners' diagnostic and intervention performance for domestic violence. Western Journal of Nursing Research, 20, 536-553.

Hook, M. P. (2000). Help seeking for violence: View of survivors. AFFILIA, 15, 390-408.

Leininger, M. (1985). Qualitative Research Methods in Nursing. Philadelphia: Saunders.

Leininger, M. (2001). Culture Care Diversity and Universality: A Theory of Nursing. Boston: Jones and Bartlett.

McFarlane, J., Christoffel, K., Bateman, L., Miller, V., \& Bullock, L. (1991). Assessing for abuse: Self-report versus nurse interview. Public Health Nursing, 8, 245-250.

McMurray, A., \& Moore, K. (1994). Domestic violence: Are we listening? Do we see? Australian Journal of Advanced Nursing, 12(1), 23-28. 
Rodriguez, R. (1999). The power of the collective: Battered migrant farmworker women creating safe spaces. Health Care for Women International, 20, 417-426.

Rodriquez, M. A., Bauer, H. M., Flores-Ortiz, Y., \& Szkupinski-Quiroga, S. (1998). Factors affecting patient-physician communication for abused Latina and Asian immigrant women. The Journal of Family Practice, 47, 309-311.

Smith, P., Danis, M., \& Helmick, L. (1998). Changing the health care response to battered women: A health education approach. Family and Community Health, 20(4), 1-18.

Stasiak, D. (2001). Culture care theory with Mexican-Americans in an urban context. In M. Leininger (Ed.), Culture Care Diversity and Universality: A Theory of Nursing. (pp. 179_ 201) Boston: Jones and Bartlett.

Varcoe, C. (2001). Abuse obscured: An ethnographic account of emergency nursing in relation to violence against women. Canadian Journal of Nursing Research, 32(4), 95-115.

Warda, M. (2000). Mexican American's perceptions of culturally competent care. Western Journal of Nursing Research, 22, 203-224.

Webster, J., Stratigos, S., \& Grimes, K. (2001). Women's responses to screening for domestic violence in a health-care setting. Midwifery, 17, 289-294.

West, C., Kantor, G., \& Jasinski, J. (1998). Sociodemographic predictors and cultural barriers to help-seeking behavior by Latina and Anglo American battered women. Violence and Victims, 13, 361-375.

Wilson, C., Cesario, S., Fredland, N., Walsh, T., McFarlane, J., Gist, J., Malecha, A., \& Schultz, P. (2001). Primary healthcare provider's lost opportunity to help abused women. Journal of the American Academy of Nurse Practitioners, 12, 565-570. 